\title{
DEVELOPING A MASTER OF SCIENCE IN INFORMATION TECHNOLOGY WITH A BUSINESS FOCUS
}

\author{
Loreen M. Powell, Bloomsburg University of Pennsylvania, lpowell@bloomu.edu \\ James K. Krause, Bloomsburg University of Pennsylvania, jkrausei@bloomu.edu \\ Sheila Jones, Bloomsburg University of Pennsylvania, sjones@bloomu.edu
}

\begin{abstract}
Employment growth within the information-technology (IT) field is expected to outpace the number of IT professionals and IT manager positions available in the near future. Research predicts that the significant shortage of employees with technical skills may yield a global competitiveness crisis for United States. The need to retool existing employees, as well as further train potential IT employees, is essential. Furthermore, since IT is a dynamic and fast-paced discipline, it is critically important that academia responsible for educating the future information technologists and computing professionals of the world understand the needs of the external business environment where the technology is utilized. One possible action to help address this need is to develop a Master of Science in IT (MSIT) degree program that inculcates the desired business related soft skills and develops students understanding of current IT practices coupled with a broader awareness of the impact of their discipline on businesses. This research provides a framework and curriculum model a MSIT program within a college of business. Implications include the development of MSIT programs with a business and soft skills focus.
\end{abstract}

Keywords: Information Technology (IT), Master Degree Program, Soft Skills, IT Shortage, Curriculum Development

\section{INTRODUCTION}

Information Technology (IT) affects every business. Globally, IT has become a critical factor in the economic development of nations. As the integration and use of IT continues to advance, innovate and drive new possibilities for businesses, the need for IT professionals also increases (Powell \& Wimmer, 2016). The McKinsey Global Institute forecasts a need for more than 1.5 million more managers and IT analysts with both analytical and technical skills (Manyika, Chui, Brown, Bughin, Dobbs, Roxburgh, and Byers, 2011). The supply of IT professionals who can ask the right questions to help support, analyze, and examine the key IT metrics and decomposition business models are limited. Thus, the supply of IT professionals is not enough to meet the current and foreseeable demands of businesses within the United States (Powell \& Wimmer; 2016). There are several ways to address this problem. However, providing further education and training is one of the most valid and accepted ways to address career shortages. Despite the widespread use of undergraduate IT related degrees worldwide; there are a limited number of gradate MSIT (MSIT) degrees within the US. This study seeks to construct a curriculum framework and curriculum model for creating a MSIT program within a college of business.

This work has practical implications for higher education institutions, faculty, and MSIT degree programs by explaining the mapping and development of the curriculum. The remainder of this paper is structured as follows: a brief review of the literature, methodology, results, and conclusion.

\section{LITERATURE REVIEW}

According to Pennsylvania (PA) State Civil Services Commission (2016), "nearly all Commonwealth agencies utilize IT professionals. The demand remains strong for qualified individuals in this career field". In 2015, Geisinger Health System in PA began to rapidly acquire additional health care providers such as AtlantiCare in New Jersey. With this and several other acquisitions came technology integration and innovation (Commins, 2015). Thus, healthcare IT professionals were needed and still are needed. According the US Bureau of Labor Statistics 
(2015), occupational groups related to healthcare are projected to have the fastest employment growth and IT or computer and mathematical fields have the next fastest employment growth at $13 \%$.

Moore (2016) predicts that there will be an epic shortage of IT professionals within the US in the near future. He believes the shortage could potential cause a global competitiveness crisis for US that could take years to recover. Hence, he strongly urges that we need to retool and educate individuals to enter the IT field.

\section{Soft Skills and Business Acumen}

The importance of soft-skills and business acumen is essential to the program. Research supports this focus. For example, "research conducted by Bassellier and Benbasat (2004) stated that "Organizations need to educate and train their IT professionals to be more business oriented, given that they invest substantial amounts of money in IT and often depend on IT to gain competitive advantage, to avoid a competitive disadvantage, and to ensure the survival of the business" pp.677. Their study identified specific business knowledge, skills and abilities including, but not limited to, organization unit, leadership, and inter-personal communication" (Hendon, Powell \& Wimmer, 2017).

A recent study by Stevens and Norm (2016) recognized the current and predicted global shortage of IT workers. They argued that the shortage is gaining attention from government policy-makers to explore overseas recruiting options. Furthermore, they recognized business needs of soft skills in IT graduates (Hendon, Powell \& Wimmer, 2017).

\section{Difference in Information Technology (IT), Computer Science (CS) and Management Information Systems (MIS) Degrees}

It is important to note that there are several differences between an IT, computer science, and management information system degree. The concept of a MSIT within a College of Business environment has been supported by research for many years. IT and related computing degree programs, including, but not limited to, Management Information Systems and Information Systems, have been taught from a business perspective. Additionally, because IT is such a vast and dynamic degree, it may also be taught from a computer science perspective. When an IT degree program is taught from a computer science perspective, emphasis is placed on programming and computer hardware rather than soft-skills and business acumen (Connolly, Lunt, Miller, \& Powell, 2015; Lunt \& Ekstorm, 2008; Lunt, Ekstrom, Lawson, Kamali, Miller, \& Gorka, 2004). Moreover, when an IT degree is taught from a management information systems perspective, emphasis is placed on information systems and their use in business and other organizations. Specifically, management information system degrees "learn about computer databases, networks, computer security" (The College Board, 2017).

\section{METHODOLOGY: REVIEW OF EXISTING MSIT PROGRAMS}

The MSIT program has been designed from an evaluation of existing IT degree programs, scholarly research, and information and competency models from several key professional organizations including, but not limited to, Association of Computing Machinery (ACM), Special Interest Group in Information Technology Education, (SIGITE), Education Special Interest Group (EDSIG)of the Association of Information Technology (AITP) Professionals (EDSIG), the International Association for Computer Information Systems (IACIS) and Association of Information Systems (AIS).

To develop the program, a review of other Master of Science in IT Programs within Pennsylvania was completed. Using the Princeton Review website, a query search was conducted (Spring 2016) with the following criteria: graduate degrees, IT majors, within the state of Pennsylvania. The results revealed only two (2) universities (Carnegie Mellon University and Temple University) meeting the search criteria.

Upon further inspection of the two (2) university's websites, Temple University has a Master of Science in Information Science and Technology rather than a MSIT. Hence, another search was conducted for graduate computing degrees in the United States. A total of 108 IT/computing graduate degree programs were found. A review of the 108 graduate computing programs was conducted and 18 graduate degree programs, which include a business focus, were selected and used for the creation of this program. Table 1 provides a summary of the universities selected to benchmark curriculum. 
Table 1. Summary of Graduate Computing Degrees Used for Creating the Program

\begin{tabular}{ll}
\hline University & Degree Program \\
\hline Abraham Lincoln University & Master of Science in IT \\
Aspen University & Master of Science in IT \\
Bentley University & Master of Science in IT \\
California State University-Fullerton & Master of Science in IT \\
Carnegie Mellon & Master of Science in IT \\
Columbia University & Master of Science in Technology Management \\
DePaul University & Master of Business IT \\
Illinois Institute of Technology & Master of Science in IT Management \\
Florida Institute of Technology & Master of Science in IT \\
LaSalle University & Master of Science in IT Leadership \\
Loyola University, Chicago & Master of Science in IT \\
Rutgers & Master of Science in IT \\
Towson University & Master of Science in Applied IT \\
University of Maryland University College & Master of Science in IT \\
University of Massachusetts Lowell \& Boston & Master of Science in IT \\
University of Massachusetts Boston & Master of Science in IT \\
University of the Potomac & Master of Science in IT \\
University of Pittsburgh & Master of Science in Information Science \\
Walden University & Master of Science in IT \\
\hline
\end{tabular}

\section{RESULTS: MSIT WITH A BUSINESS FOCUS}

The MSIT degree program responds to the rapid and dynamic technology changes and challenges that businesses encounter. The program focuses on the practical theories (knowledge), skills, and abilities of how IT affects corporate strategy and operations. Specifically, the program aims to implement best practices consistent with current IT principles supported by key IT metrics and decomposition models; apply technology solutions to increase effectiveness and efficiency; build effective global project management teams; develop, manage and store IT to assure quality and value of information; and analyze and synthesize data to identify possible business opportunities and problems.

The program is unlike many graduate IT/computing degree programs, most of which are found within computer science departments and lack a business focus. Typically, within those programs, students develop the technical skills necessary to prepare them for the rapidly evolving IT industry. However, the greater difficulty for many computing programs is how to inculcate the desired business related soft skills and how to develop in their students an understanding of current IT practices coupled with a broader awareness of the impact of their discipline on businesses.

The program is driven by design to focus on leveraging technology to achieve management objectives, identify business opportunities, and solve business problems. Hence, the goal is to produce IT professionals who know how to integrate and innovate rapidly evolving global IT within a business environment. As such, the program will have a managerial and innovation influence. Specifically, the managerial influence will focus on developing students' business and leadership skills/abilities to become change agents within a business. The innovation influence will focus on developing students' technology skills and abilities so they may become innovation catalysts within a business. Figure 1 illustrates the design of the MSIT within a business focus. 


\section{Master of Science in Information Technology}

(within the College of Business)
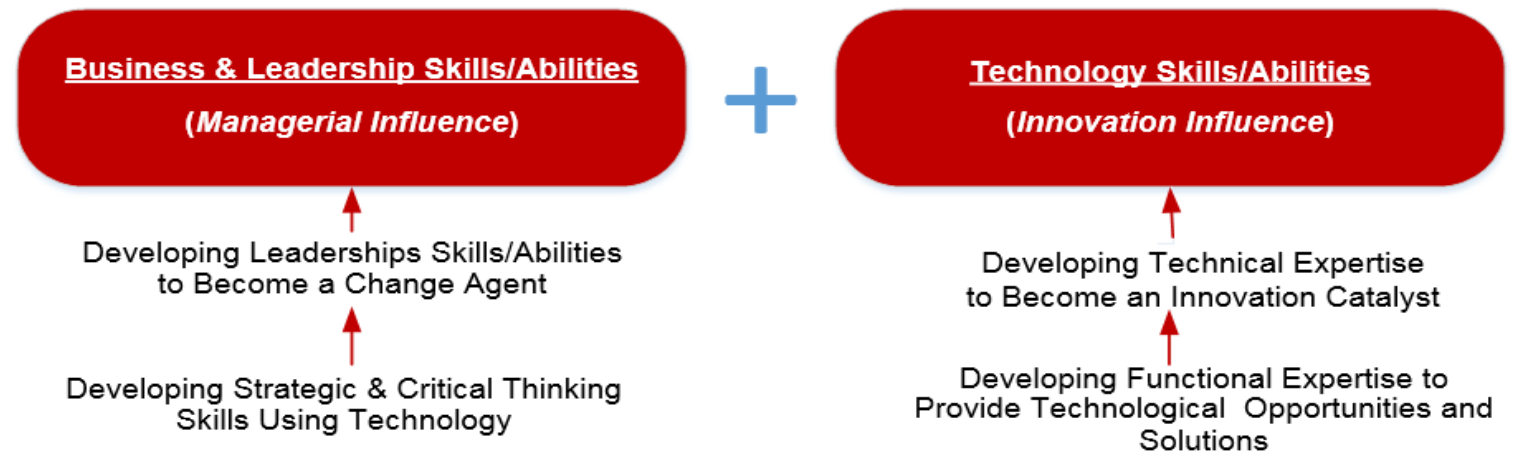

Figure 1. MSIT Design Approach

\section{Student Learning Outcomes (SLOs)}

The MSIT degree program's primary mission is to provide the managerial skills and knowledge necessary to prepare students for success in entry and mid-level IT positions. As previously discussed, the program is driven, by design, to focus on leveraging technology to achieve management objectives, identify business opportunities and solve problems. The goal is to produce IT professionals who know how to integrate and innovate rapidly evolving global IT within a business environment. As such, the program will have a managerial and innovation influence. Specifically, the managerial influence will focus on developing business and leadership skills/abilities to become change agents within a business. The innovative influence focuses on developing technology skills and abilities to become an innovation catalyst within a business.

There are five key program SLOs. Table 2 list the Program's SLOs.

Table 2. Program SLOs

SLO Description

1. Develop, analyze and synthesize data to identify possible business opportunities, solve problems and recognize innovation

\section{Apply technology} solutions to increase effectiveness and efficiency of an organization
Students will

a. Create information technology tools, applications and systems

b. Use information systems and software decision-making tools to analyze and mine data for outcomes

c. Identify opportunities for innovation and devise strategies and solutions

d. Assess the impact of external technology influences and threats on a company's key processes and operations

Students will

a. Simulate information technology tools used within the current organizations

b. Integrate functional expertise to provide technological opportunities 


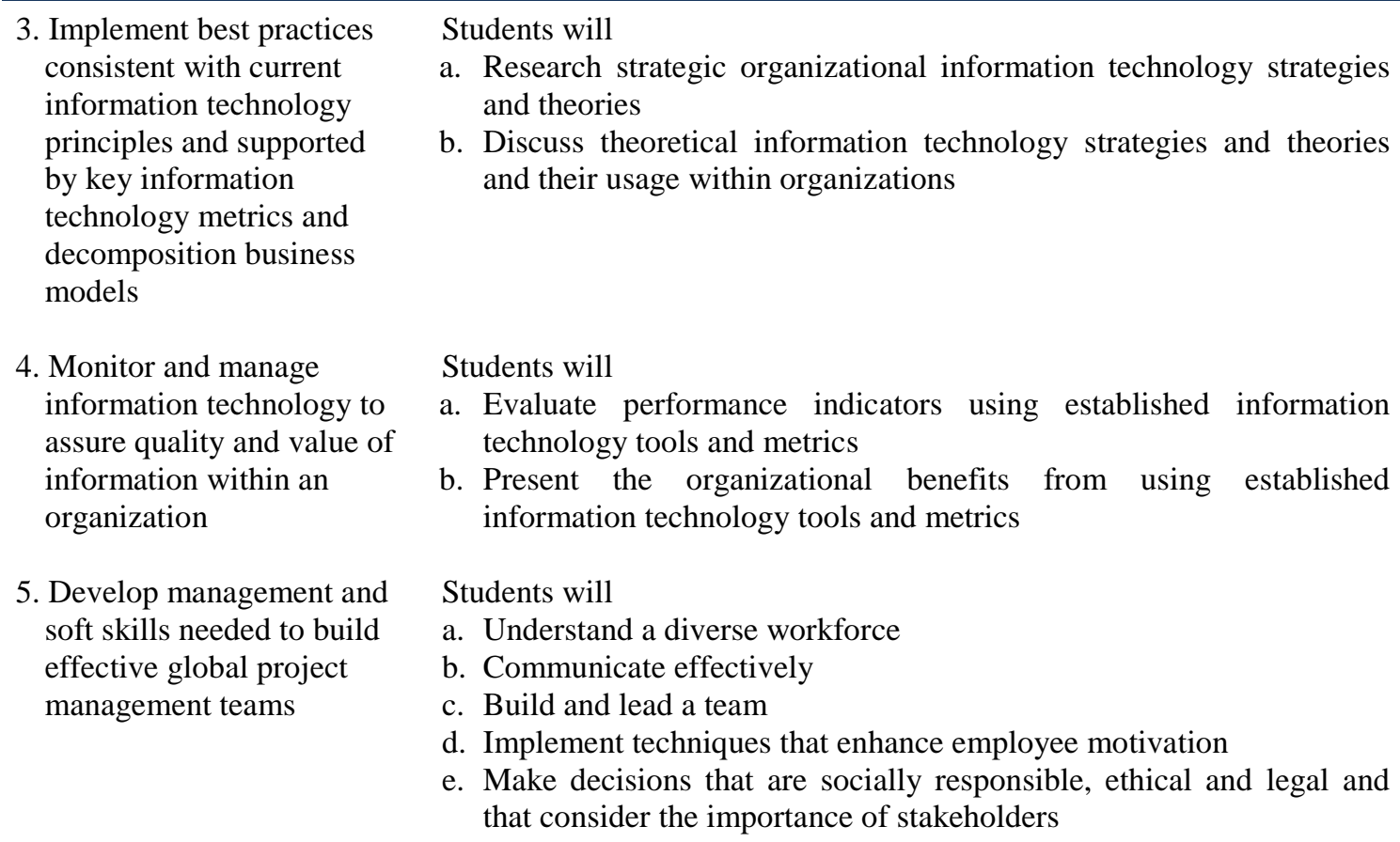

5. Develop management and soft skills needed to build effective global project management teams

Students will

a. Research strategic organizational information technology strategies and theories

b. Discuss theoretical information technology strategies and theories and their usage within organizations

Students will

a. Evaluate performance indicators using established information technology tools and metrics

b. Present the organizational benefits from using established information technology tools and metrics

Students will

a. Understand a diverse workforce

b. Communicate effectively

c. Build and lead a team

d. Implement techniques that enhance employee motivation

e. Make decisions that are socially responsible, ethical and legal and that consider the importance of stakeholders

\section{Curriculum}

As listed in table 3, the MSIT is a 30-credit-hour program consisting of ten (10) three-credit courses. There are seven (7) required courses, two (2) electives, and a required practicum. Students without sufficient preparation also complete prerequisite foundation course such as a Principles of Information a Technology. Students with an undergraduate degree in a computing or business discipline will likely have taken a similar course. Students with non-computing undergraduate degrees will usually be lacking this course and therefore must take the foundation course to make up for this deficit. Foundation courses are not included in the 30 hours of credit required for the MSIT degree.

Table 3. Master of Science Degree in Information Technology (30 Credits)

\section{Core Course (21 Credits) Seven Required Courses}

21 credits

Business Application Development and Evaluation ITM 510

Web \& Mobile Development for Business ITM 512

Data Science for Business ITM 522

Enterprise Networks Architectures, Platforms and Security ITM 530

Managing Innovation and Projects ITM 570

Strategic Information Technology Management ITM 590

Data Management for Business Intelligence ITM 592

\section{Elective Specialty Courses (6 credits) Two Elective Specialty Courses}

6 credits

Principled Leadership, Ethics, \& Professional Development MGMT 515

Managing People in Organizations MGMT 567

E-Business Technologies for the Global World ITM 550

Special Topics in IT ITM 598

Business Research BUSED 521 
IT Practicum ITM 594

The core courses cover the essential knowledge of IT in the ACM and IEEE-CS (2017) IT Curricula Report. Specifically, basic function areas such as object-oriented programming, web and mobile development for business, enterprise architectures, platforms and security, as well as data science/analytics for business are included in the core course. Additionally, it is important to note that all content and cases in core courses have a business focus

The electives are variety of courses in soft skills, research, and technology. The technology elective aids further advancing of subject matters integrated throughout courses in the core curriculum, as well as help students learn how to manage, lead, and innovate. Students have the option to select which courses will better enhance their skill set.

The capstone course is an IT practicum. The Practicum creates an applied learning experience that integrates and expands upon the knowledge learned in a technology related graduate program. It may include either a consultancy in a dynamic business environment, or an applied report within a corporation or other economic entity. Students are responsible for a written proposal, a final written report of professional quality, and an oral presentation to graduate faculty and relevant stakeholders in the community.

Each of the courses were benchmarked against existing MSIT programs. Table 4 provides the mapping of courses against other MSIT programs.

Table 4. Similar Content/Courses in Their Program

\begin{tabular}{|c|c|c|c|c|c|c|c|c|c|c|c|c|c|c|}
\hline \multirow[t]{2}{*}{ Universities } & \multicolumn{7}{|c|}{ BU Core Courses } & \multicolumn{6}{|c|}{ BU Elective Courses } & \multirow{2}{*}{ 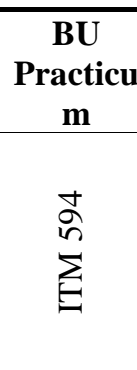 } \\
\hline & 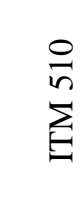 & 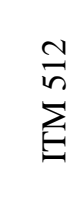 & 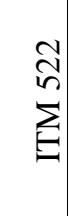 & 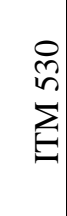 & $\begin{array}{l}\stackrel{?}{n} \\
\sum \\
\sum\end{array}$ & $\stackrel{8}{\stackrel{8}{n}}$ & $\begin{array}{l}\Omega \\
\tilde{n} \\
\sum \\
\Xi\end{array}$ & $\begin{array}{l}n \\
n \\
5 \\
0 \\
\Sigma\end{array}$ & 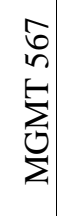 & 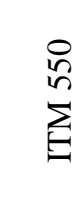 & 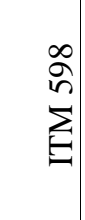 & $\begin{array}{l}\overrightarrow{\tilde{n}} \\
\hat{n} \\
\underline{n} \\
\vec{n} \\
0\end{array}$ & 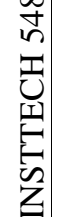 & \\
\hline $\begin{array}{l}\text { Abraham Lincoln } \\
\text { University (MSIT) }\end{array}$ & & & $\begin{array}{l}\mathrm{S} \\
\mathrm{C}\end{array}$ & $\begin{array}{l}\mathrm{S} \\
\mathrm{C}\end{array}$ & $\begin{array}{l}\mathrm{S} \\
\mathrm{C}\end{array}$ & $\mathrm{SC}$ & & & & $\mathrm{SC}$ & $\mathrm{SC}$ & & & SC \\
\hline $\begin{array}{l}\text { Aspen University } \\
\text { (MSIT) }\end{array}$ & $\mathrm{SC}$ & & & $\begin{array}{l}\mathrm{S} \\
\mathrm{C}\end{array}$ & & $\mathrm{SC}$ & & & & & $\mathrm{SC}$ & & & $\mathrm{SC}$ \\
\hline $\begin{array}{l}\text { Bentley University } \\
\text { (MSIT) }\end{array}$ & $\mathrm{SC}$ & SE & $\begin{array}{l}\mathrm{S} \\
\mathrm{C}\end{array}$ & $\begin{array}{l}\mathrm{S} \\
\mathrm{C}\end{array}$ & $\begin{array}{l}\mathrm{S} \\
\mathrm{C}\end{array}$ & & & & & & $\mathrm{SC}$ & & & $\mathrm{SC}$ \\
\hline $\begin{array}{l}\text { California State } \\
\text { University-Fullerton } \\
\text { (MSIT) }\end{array}$ & $\mathrm{SC}$ & $\begin{array}{l}\mathrm{S} \\
\mathrm{C}\end{array}$ & $\begin{array}{l}\mathrm{S} \\
\mathrm{C}\end{array}$ & $\begin{array}{l}\mathrm{S} \\
\mathrm{C}\end{array}$ & & & & & & $\mathrm{SC}$ & & & & $\mathrm{SC}$ \\
\hline $\begin{array}{l}\text { Carnegie Mellon } \\
\text { (MSIT) }\end{array}$ & $\mathrm{SC}$ & & $\begin{array}{l}\mathrm{S} \\
\mathrm{C}\end{array}$ & $\begin{array}{l}\mathrm{S} \\
\mathrm{C}\end{array}$ & $\begin{array}{l}\mathrm{S} \\
\mathrm{C}\end{array}$ & & SE & $\mathrm{SC}$ & & $\mathrm{SC}$ & $\mathrm{SC}$ & & & \\
\hline $\begin{array}{l}\text { Columbia } \\
\text { University (MSTM) }\end{array}$ & $\mathrm{SC}$ & & $\begin{array}{l}\mathrm{S} \\
\mathrm{C}\end{array}$ & $\begin{array}{l}\mathrm{S} \\
\mathrm{C}\end{array}$ & $\begin{array}{l}\mathrm{S} \\
\mathrm{C}\end{array}$ & $\mathrm{SC}$ & $\mathrm{SC}$ & $\mathrm{SC}$ & & & & & & $\mathrm{SC}$ \\
\hline $\begin{array}{l}\text { DePaul University } \\
\text { (MBIT) }\end{array}$ & & & & $\begin{array}{l}\mathrm{S} \\
\mathrm{C}\end{array}$ & $\begin{array}{l}\mathrm{S} \\
\mathrm{C}\end{array}$ & $\mathrm{SC}$ & & $\mathrm{SC}$ & & & & & & \\
\hline
\end{tabular}


Issues in Information Systems

Volume 19, Issue 4, pp. 162-170, 2018

\begin{tabular}{|c|c|c|c|c|c|c|c|c|c|c|c|}
\hline $\begin{array}{l}\text { Florida Institute of } \\
\text { Technology (MSIT) }\end{array}$ & & & $\begin{array}{l}\mathrm{S} \\
\mathrm{C}\end{array}$ & & & $\mathrm{SC}$ & $\mathrm{SC}$ & & $\mathrm{SC}$ & & \\
\hline $\begin{array}{l}\text { Illinois Institute of } \\
\text { Technology } \\
\text { (MSITM) }\end{array}$ & & & $\begin{array}{l}\mathrm{S} \\
\mathrm{C}\end{array}$ & $\begin{array}{l}\mathrm{S} \\
\mathrm{C}\end{array}$ & $\begin{array}{l}\mathrm{S} \\
\mathrm{C}\end{array}$ & $\mathrm{SC}$ & $\mathrm{SE}$ & & & SE & \\
\hline $\begin{array}{l}\text { LaSalle University } \\
\text { (MSIT Leadership) }\end{array}$ & & & & & & & & & & & \\
\hline $\begin{array}{l}\text { Loyola University, } \\
\text { Chicago (MSIT) }\end{array}$ & ST & ST & ST & ST & $\begin{array}{l}\mathrm{S} \\
\mathrm{C}\end{array}$ & & ST & & & & $\mathrm{SC}$ \\
\hline Rutgers (MSIT) & SE & & & SE & & SE & $\mathrm{SC}$ & & & & $\mathrm{SC}$ \\
\hline $\begin{array}{l}\text { Towson } \\
\text { University(MSAIT) }\end{array}$ & SC & $\begin{array}{l}\mathrm{S} \\
\mathrm{C}\end{array}$ & $\begin{array}{l}\mathrm{S} \\
\mathrm{C}\end{array}$ & $\begin{array}{l}\mathrm{S} \\
\mathrm{C}\end{array}$ & $\begin{array}{l}\mathrm{S} \\
\mathrm{C}\end{array}$ & & SE & & & $\mathrm{SE}$ & $\mathrm{SC}$ \\
\hline $\begin{array}{l}\text { University of } \\
\text { Maryland } \\
\text { University College } \\
\text { (MSIT) }\end{array}$ & $\mathrm{SE}$ & & SE & $\begin{array}{l}\mathrm{S} \\
\mathrm{C}\end{array}$ & $\begin{array}{l}\mathrm{S} \\
\mathrm{C}\end{array}$ & $\mathrm{SC}$ & SE & & & & \\
\hline $\begin{array}{l}\text { University of } \\
\text { Massachusetts } \\
\text { Lowell \& Boston } \\
\text { (MSIT) }\end{array}$ & $\mathrm{SC}$ & & SE & $\begin{array}{l}\mathrm{S} \\
\mathrm{C}\end{array}$ & $\begin{array}{l}\mathrm{S} \\
\mathrm{C}\end{array}$ & & SE & & & & \\
\hline $\begin{array}{l}\text { University of the } \\
\text { Potomac (MSIT) }\end{array}$ & & & \begin{tabular}{|l|}
$\mathrm{S}$ \\
$\mathrm{C}$
\end{tabular} & $\begin{array}{l}\mathrm{S} \\
\mathrm{C}\end{array}$ & & $\mathrm{SC}$ & $\mathrm{SC}$ & $\mathrm{SC}$ & & & \\
\hline $\begin{array}{l}\text { University of } \\
\text { Pittsburgh (MSIS) }\end{array}$ & & $\begin{array}{l}\mathrm{S} \\
\mathrm{C}\end{array}$ & $\begin{array}{l}\mathrm{S} \\
\mathrm{C}\end{array}$ & $\begin{array}{l}\mathrm{S} \\
\mathrm{C}\end{array}$ & & & $\mathrm{SC}$ & & $\mathrm{SC}$ & & $\mathrm{SC}$ \\
\hline $\begin{array}{l}\text { Walden University } \\
\text { (MSIT) }\end{array}$ & ST & ST & ST & ST & $\begin{array}{l}\mathrm{S} \\
\mathrm{C}\end{array}$ & & ST & & & & \\
\hline
\end{tabular}

$\mathrm{SC}=$ Similar Course, $\mathrm{SE}=$ Similar Elective, $\mathrm{ST}=$ Similar Course in a Specific Track

Additionally, in the creation of the program, each course was carefully mapped to the program's SLOs. Table 5 provides the mapping the program's curriculum to program's SLOs.

Table 5. Mapping of Program SLOs to Courses

\begin{tabular}{|c|c|c|c|c|c|c|c|c|c|c|c|c|c|c|}
\hline \multirow[t]{2}{*}{ Program SLOs } & \multicolumn{7}{|c|}{ Core Courses } & \multicolumn{6}{|c|}{ Elective Courses } & Practicum \\
\hline & $\begin{array}{l}\frac{0}{n} \\
\sum \\
\underline{n}\end{array}$ & $\begin{array}{l}N \\
\stackrel{N}{n} \\
\sum \\
\Xi\end{array}$ & 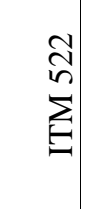 & $\begin{array}{l}0 \\
n \\
n \\
\sum_{E}^{n}\end{array}$ & $\begin{array}{l}\stackrel{R}{n} \\
\sum_{E} \\
=\end{array}$ & 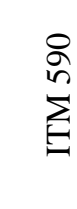 & $\begin{array}{l}N \\
\tilde{n} \\
\sum\end{array}$ & $\begin{array}{l}n \\
n \\
5 \\
0 \\
\Sigma\end{array}$ & $\begin{array}{l}\hat{0} \\
n \\
\vdots \\
0 \\
\Sigma\end{array}$ & $\begin{array}{l}0 \\
n \\
i \\
\sum\end{array}$ & $\begin{array}{l}\infty \\
\stackrel{\infty}{n} \\
\sum \\
\Xi\end{array}$ & 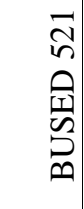 & 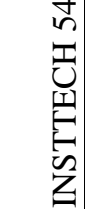 & $\begin{array}{l}\text { Dे } \\
\text { in }\end{array}$ \\
\hline SLO 1 & & & $\mathrm{~B}$ & & & & A & & & I & $\mathrm{C}$ & I & I & A \\
\hline SLO 2 & B & I & & I & B & I & I & & & I & $\mathrm{C}$ & & & A \\
\hline SLO 3 & & & & $\mathrm{~B}$ & I & I & I & & & & $\mathrm{C}$ & I & & A \\
\hline SLO 4 & $\mathrm{~B}$ & & & I & I & I & & & & I & $\mathrm{C}$ & I & $\mathrm{I}$ & A \\
\hline SLO 5 & $\mathrm{~B}$ & & $\mathrm{~B}$ & & $\mathrm{I}$ & & & $\mathrm{A}$ & $\mathrm{A}$ & & $\mathrm{C}$ & $\mathrm{I}$ & & $\mathrm{A}$ \\
\hline
\end{tabular}

$\mathrm{B}=$ Concept/Theory/Skill is Introduced at the "Beginning Level"

$\mathrm{I}=$ Concept/Theory/Skill is Reinforced at the "Intermediate Level"

$\mathrm{A}=\mathrm{Concept} /$ Theory/Skill is Assessed at the "Advanced Level"

$\mathrm{C}=\mathrm{Concept} /$ Theory/Skill may be Introduced, Reinforced, or Assessed at any level 


\section{CONCLUSION}

In summary, the MSIT degree program has been designed from an evaluation of existing IT degree programs, scholarly research, and information and competency models from several key professional organizations.

Based upon the development of this MSIT with a business focus, we believe that students will be better prepared for today's mid-level IT careers. Research has shown that business acumen and other soft skills are needed for IT careers (Hendon, Powell, \& Wimmer, 2017). Thus, this MSIT with a business focus is significant because it supports industry studies that show that business acumen and other soft skills are essential for IT careers.

This program design is not without limitations. Specifically, this program design has not been assessed. The expected start date is slated for fall 2019. Thus, the assessment of this program should be provided in the future. However, this program design provides a framework and curriculum model a MSIT program with a business focus.

\section{REFERENCES}

ACM and IEEE-CS (2017) Information Technology Curricula 2017. Retrieved from https://www.acm.org/binaries/content/assets/education/curricula-recommendations/it2017.pdf

Bassellier, G. \& Benbasat, I. (2004). Business competence of information technology professionals: Conceptual development and influence on it-business partnerships, MIS Quarterly, 28(4), 673-694.

Bureau of Labor Statistics (2015, December) Projections of occupational employment, 2014-24. Retrieved from http://www.bls.gov/careeroutlook/2015/article/projections-occupation.htm

Commins, J. (2015). Business roundup: Geisinger, Atlantic care finalize acquisition. Retrieved from http://www.healthleadersmedia.com/community-rural/business-roundup-geisinger-atlanticare-finalizeacquisition

Connolly, R. Lunt, B., Miller, J., \& Powell, L. (2015). Towards a better understanding of the different computing disciplines (Panel Discussion), In Proceedings of the 16th Annual Conference on Information Technology Education (ACM SIGITE), Chicago, IL.

Hendon, M. Powell, L. \& Wimmer, H. (2017). Emotional intelligence and communication levels in information technology professionals. Computers in Human Behaviour. 7(2017) 165-171.

Lunt, B., M. \& Ekstrom, J., K. (2008). What distinguishes each of the major computing disciplines? Sixth LACCEI International Latin American and Caribbean Conference for Engineering and Technology (LACCEI'2008),

Tegucigalpa, Honduras. Retrieved from http://www.laccei.org/LACCEI2008-Honduras/Papers/CD092_Lunt.pdf

Lunt, B.M., Ekstrom, J.J., Lawson, E.A., Kamali, R., Miller, J., \& Gorka, H.R. (2004). Defining the IT curriculum: The results of the past 21/2 years; In Proceedings of the International Conference on Engineering Education and Research, Olomouc, Czech Republic. Retrieved from http://www.acm.org

Manyika, J., Chui, M., Brown, B., Bughin, J., Dobbs, R., Roxburgh, C., \& Byers, A., H. (2009). Big data: The next frontier for innovation, competition and productivity. Retrieved from http://www.mckinsey.com/businessfunctions/business-technology/our-insights/big-data-the-next-frontier-for-innovation

Moore (2016). Computer science is the key to America's skills crisis. Crunch Network. Retrieved from http://techcrunch.com/2016/03/04/computer-science-is-the-key-to-americas-skills-crisis/

Pennsylvania State Civil Services Commission (2016). Information technology: Do you enjoy the challenges of today's technology? Retrieved from http://www.scsc.pa.gov/Job-Seekers/career-

paths/Pages/InformationTechnology.aspx\#.Vv0pfaPD-pq 


\section{Issues in Information Systems}

Volume 19, Issue 4, pp. 162-170, 2018

Powell, L. M. \& Wimmer, H. (2016). Parental Perceptions and Recommendations of Computing Majors: A Technology Acceptance Model Approach. Proceedings of the Education Special Interest Group (EdSig) of the Association of Information Technology Professionals (AITP) Conference on Information Systems and Computing Education, Las Vegas, Nevada

Stevens, M. \& Norm, R. (2016). Industry expectations of soft skills in information technology graduates. Proceedings of the Australasian Computer Science Week Multi-conference (ACSW '16). ACM, New York, NY, USA, 13, 1-9.

The College Board (2017). Major: Management Information Systems. Retrieved from: https://bigfuture.collegeboard.org/majors/business-management-information-systems

\section{Acknowledgement}

A special thank you is extended to the journal reviewers, Bloomsburg University of Pennsylvania's Office of the President, Provost Office, Office of Planning and Assessment (OPA), Dean and Interim Dean of the Zeigler College of Business, BUCC, Graduate Counsel/Curriculum Committee, ZCOB CC, The Department of Innovation, Technology \& Supply Chain Management, Meaghan Fuhrman, Ruhul Amin, Darrin Kass, John Okpara, Mary Ellen Alu, and Dan Powell for all their guidance and valuable feedback. 